Int. Archs Allergy appl. Immun. 1979;60:I-V

\title{
Contents, Vol. 60, 1979
}

\section{No.l}

Original Paper

Bresnihan, B.; Lavalle, C, and Jasin, H. E.:

Protein Synthesis and Secretion by Activated

Human Lymphocytes 1

Schultz, R. T.: Antibody Formation in Experi

mental Amyloidosis 9

Skoog, M.-L. and Groth, O.: Effect of Cyclo-phosphamide on the Cellular Infiltrate in

Experimental Allergic Contact Dermatitis . 22

Altboum, I. and Pick, E.: Antigen and Mitogen Induced Production of Macrophage Migration

Inhibitory Factor in the Mouse ... 29

Walker, J. R.: Complement Activation by Rat

Platelets: Its Significance to Inflammation in

the Rat 44

Mansour, A. and Nelson, D. S.: Effect of Hy-drocortisone, Cyclophosphamide, Azathio-prine and Methotrexate on Contaneous Delayed and Arthus Hypersensitivity in the Rat 50

Aim, P. E. and Bloom, G. D.: Effect of Nor-

epinephrine on in vitro Histamine Release

from Rat Mast Cells 60

Aukrust, L. and Borch, S. M.: Partial Purifica

tion and Characterization of Two Clado-

sporium herbarum Allergens 68

Arisz, L.; Noble, B.; Milgrom, M.; Brentjens, J. R., and Andres, G. A.: Experimental Chronic

Serum Sickness in Rats. A Model of Immune Complex Glomerulonephritis and Systemic

Immune Complex Deposition . . 80

Forsdyke, D. R.: Serum Factors Affecting the Incorporation of [3H]thymidine by Lymphocytes

Stimulated by Antigen. IV. Comparison of Enhancement by Heated $\left(56^{\circ} \mathrm{C}\right)$ Serum and by 2-

Mercaptoethanol .... 89

Short Communications

Lindahl-Kiessling, K. and Karlberg, I.: High

Oxygen Pressure Inhibits DNA Synthesis in

Mitogen-Activated Lymphocytes 97

Attallah, A. M. and Strong, D. M.: Differential Effects of Interferon on the MHC Expression of

Human Lymphocytes. Enhanced Expression of HLA without Effect on la .... 101

Conroy, M. C.; Adkinson, N. F., jr., and Lich-

tenstein, L. M.: Passive Sensitizatíon of Hu

man Basophils: Evidence for Heterogeneity

in the IgE Molecule 106

Krüger, P. G. and Bloom, G. D.: Enigma of Disodium Cromoglycate Action on Mast Cells 110 
Nishimaki, T.; Kano, K., and Milgrom, F.:

Paul-Bunnell Antigen in Malignancies and

Rheumatoid Arthritis 115

Varia 120

No. 2

Original Paper

Fujita, K.; Ikeda, T., and Tsukidate, S.: Immunological and Physicochemical Properties of a Highly Purified Allergen from Dirofilaria immitis 121

Attallah, A.M.; Yeatman, T. J.; Hoguchi, P.D., and Petricciani, J. C.: Is DNA Synthesis a Requisite for the Differentiation of B Lym phocytes into Immunoglobulin-Secreting Plasma Cells? 132

Kurup, V. P. and Fink, J. N.: Antigens of Micropolyspora faeni Strains 140

Miyachi, S.; Lessof, M. H., and Kemeny, D. M.:

Evaluation of Bee Sting Allergy by Skin Tests

and Serum Antibody Assays 148

Garrido, M. J.; Gorvin, J., and Moreno, C.:

Characterisation of the Reaginic Response

to Sulphonamides in Mice 154

Garrido, M. J. and Moreno, C.: The Use of

Hapten-Polysaccharide Conjugates for the

Induction of B-Cell Tolerance Involving IgE

Responses. II. Specific Tolerance Induced by

Sulphonamide-Substituted Levan in the

Mouse 161

Grewal, A. S. and Rouse, B. T.: Characterization of Bovine Leukocytes Involved in AntibodyDependent Cell Cytotoxicity .... 169

Attallah, A. M.; Ahmed, A., and Sell, K. W.:

In vivo Induction of Carrier-Specific Cyclo-

phosphamide-Sensitive Suppressor Cells for

Cell-Mediated Immunity in Mice 178

IV

Contents

Gauldie, J.; Horsewood, P., and Koekkebaker, M.: Nephelometric Activity as a Criterion of

Adequate Antisera for Use in Immuno-

fluorescence 186

Nordlind, K.; Sandberg, G., and Thyberg, J.: Further Studies on Splenic Material Inhibiting the Growth of Lymphocytes in vitro . . 195 
Kostiala, A. A. I.: Delayed-Type Hypersensitiv-

ity Measured as an Increase of Ear Thickness

in Guinea Pigs 207

Sharpe, T. J. and Smith, H.: Effects of Drugs on

the Acute Inflammation Following Intra-

peritoneal Injection of Antigen into Actively

Sensitised Rats 216

Book Reviews 222

No. 3

Original Paper

Vijay, H. M.; Huang, H.; Young, N. M., and

Bernstein, I. L.: Studies on Alternaria Aller

gens. I. Isolation of Allergens from Alterna

ria tenuis and Alternaria solani

229

Muiswinkel, W. B. van; Laat, A. M. M. de; Mink, J. G.; Oudenaren, A. van, and Benner, R.:

Serum Immunoglobulin Levels in Mice. Determination of the Low IgA Level in AKR Mice by an Irradiation-Resistant Factor . . 240

Bellavia, A.; Ure, J.; Ammatuna, P.; Caruso, C, and Salerno, A.: Depression of Contact

Hypersensitivity to Oxazolone in Mice Exposed to Newcastle Disease Virus .... 249

Krüger, P. G.; Apold, J., and Elsayed, S.: The

Indirect Rat Mast Cell Degranulation Test

Reconsidered 258

Salmon, H.: Surface Markers of Porcine

Lymphocytes and Distribution in Various

Lymphoid Organs 262

Gabriel, B. W. and Justus, D. E.: Quantitation of Immediate and Delayed Hypersensitivity

Responses in Trichinella-løiecteå Mice. Correlation with Worm Expulsion .... 275

Hedin, H. and Smedegård, G.: Complement Profiles in Monkeys Subjected to Aggregate

Anaphylaxis, and Following Injection of Soluble and Particulate Polysaccharides . . 286

Kristofferson, A.; Ahlstedt, S., and Hall, E.: Antigens in Penicillin Allergy. IV. Induction

of IgE Antibody Response in Mice after

Daily Treatment with Contaminated But

Not with Pure Penicillin 295

Ruitenberg, E. J.; Elgersma, A., and Kruizinga,

W.: Intestinal Mast Cells and Globule Leu

cocytes : Role of the Thymus on Their Pre

sence and Proliferation during a Trichinella

spiralis Infection in the Rat 302

Braun, D. G.; Laudien, D.; Read, S. E., and Riesen, W. F.: Persistent Clonotypes Associated with

Group A Streptococcal Poly-saccharide Antibody Response in Man . . 310

Czarnetzki, B. M.: Enhancement of Eosinophil

Leukocyte Chemotaxis by a Factor in Nor

mal Human Serum (SEF) 315

Lilliehöök, B. and Blomgren, H.: Search for Specific Effector Functions of C3H × CBA

Lymphocytes which Have Proliferated in the Spleens of Irradiated CBA Mice . . . 325 
Delia Penta, D.; Cipuzak, P. M., and Phillips,

M. E.: A Microcytotoxicity Assay Using

51Cr for Measuring Specific Cell-Mediated

and Humoral Immune Responses 332

Floyd, R. A.; Tisdale, V. G., and Lumb, J. R.: Murine Lymphoma Alkaline Phosphatase: A Cell

Membrane Carcinofetal Enzyme . . 346

Short Communication

Spitzer, J. C: Interaction of Disodium Cromo-glycate with Calcium Ions in 2-Propanol . 356

Book Reviews 359

Varia 360

No. 4

Original Paper

Attallah, A. M.; Malinin, G. I.; Houck, J. C.; Johnson, J. B., and Petricciani, J. C.: Kinetics and

Cell Killing in Dividing and Non-dividing Leukemic Cells in vitro and in vivo by Natural

Splenic Cytotoxic Factor ... 361

Attallah, A. M.; Johnson, J. B.; Malinin, G. I.;

Houck, J. C, and Petricciani, J. C: Cyto-

chemical and Ultrastructural Alteration of

Leukemic Cells by a Naturally Cytotoxic

Factor from Spleen 371

Attallah, A. M. and Folks, T.: Interferon Enhanced Human Natural Killer and Anti-

Contents

$\mathrm{V}$

body Dependent Cell-Mediated Cytotoxíc

Activity $\quad 377$

Kimura, M. and Takaya, K.: Ultrastructure of Basophilic Leukocytes and Mast Cells in Normal and Cutaneous Basophil Hyper-sensitivity-Reacted Guinea Pig Dermis . . 383

Gray, B. N. and Walker, C.: Augmentation of Lymphocyte Surface Immunogenicity following Treatment with Dimethyl-Sulphoxide . 390

Rudofsky, U. H.; McMaster, P. R. B., and Pol-

lara, B.: Studies on the Pathogenesis of Ex

perimental Autoimmune Renal Tubulointer-

stitial Disease in Guinea Pigs. VI. Induction

of Renal Lesions by Active or Passive Immu

nization of Strain 2 Guinea Pigs 398

Sandberg, G. and Ernstrom, U.: Mitotic Activity of Thymocytes in a Synthetic Tissue Culture

Medium. Effect of L-Alanine .... 407

Rozenfarb, E. and Eidinger, D.: Heterotoxicity

of Human Serum. IV. Role of the Alternative

Complement Pathway and Natural Antibody

in the Lethal Toxicity of Human Serum for

Mice 414

Rozenfarb, E. and Eidinger, D.: Heterotoxicity of Human Serum. V. Development of Hematological Abnormalities in Mice Suggestive 
of Disseminated Intravascular Coagulation and Thrombotic Thrombocytopenic Pur-

pura 427

Garrido, M. J. and Moreno, C.: The Use of Hapten-Polysaccharide Conjugates for the Induction of B-Cell Tolerance Involving IgE Responses. III. Specific Tolerance Induced by Sulphonamide-Substituted Levan in the Guinea Pig 441

Johansson, S. G. O.; Deuschl, H., and Zetter-ström, O.: Use of Glutaraldehyde-Modified Timothy Grass Pollen Extract in Nasal Hyposensitisation Treatment of Hay Fever 447 Short Communications

Ennis, M. and Pearce, F. L.: Effect of Cyclic AMP on Histamine Release Induced by

Compound 48/80 461

Kimura, I.; Yamamoto, S., and Yamura, T.: In vitro Release of Eosinophil Chemotactic Factor of Anaphylaxis (ECF-A) from Gui nea Pig Skin 465

Book Reviews 469

Author Index 473 